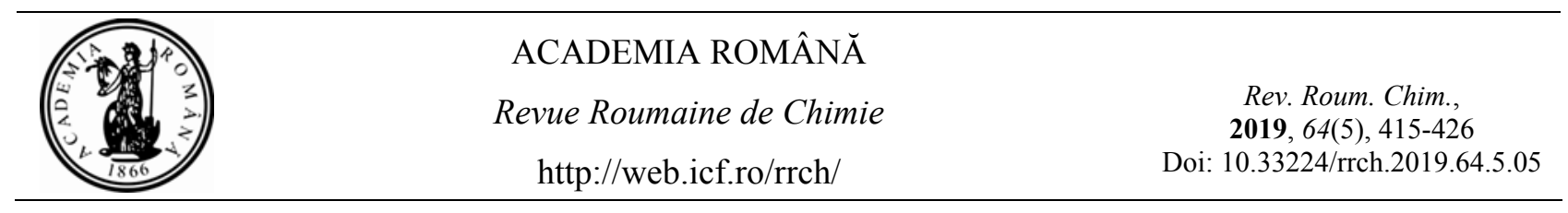

\title{
OPTIMIZATION OF Fe(III) EXTRACTION FROM HCl SOLUTIONS BY TDA/KEROSENE USING FACTORIAL DESIGN EXPERIMENTS
}

\author{
Jamal STAS ${ }^{\mathrm{a},{ }^{*}}$ and Roulana BOUZO ${ }^{\mathrm{a}}$ \\ ${ }^{a}$ Atomic Energy Commission of Syria, Department of Chemistry, POBox 6091, Damascus-Syria
}

Received January 21, 2018

The extraction of $\mathrm{Fe}^{3+}$ from aqueous $\mathrm{HCl}$ solutions using tri-n-dodecylamine (TDA)/kerosene $+10 \%$ 2-octanol has been examined. The influence of $\mathrm{HCl}$ concentration, $\mathrm{Fe}^{3+}$ concentration, organic to aqueous volume phase ratio $(\mathrm{O} / \mathrm{A})$, TDA concentration on the yield of $\mathrm{Fe}^{3+}$ extraction have been investigated using $2^{4}$ factorial design experiments. The effect of temperature on $\mathrm{Fe}^{3+}$ extraction was found to be positive and the enthalpy change of the extraction reaction was found to be $\left(\Delta \mathrm{H}^{0}=45.609 \mathrm{~kJ} \cdot \mathrm{mol}^{-1}\right)$. The saturation of the extractant with iron can be observed at a number of contact $N^{`} \geq 5$. Complete stripping of iron from the loaded TDA/kerosene can be done using $0.05 \mathrm{M}$ $\mathrm{HCl}$ at $313.15{ }^{\circ} \mathrm{K}$ and aqueous to organic volume phase ratio of $\mathrm{A} / \mathrm{O}=4$.

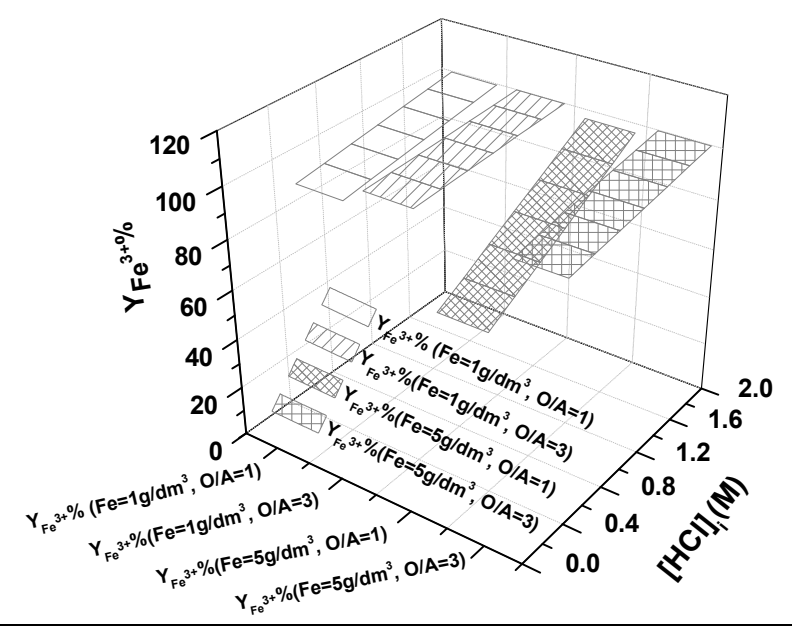

\section{INTRODUCTION}

Solvent extraction is widely used for the separation and recovery of valuable metals from aqueous solutions and industrial streams. ${ }^{1}$ Iron(III) is the remaining element after hydrometallurgical processes of recovering a number of nonferrous metal ions such as $\mathrm{Ni}^{2+}, \mathrm{Co}^{2+}, \mathrm{Cu}^{2+}, \ldots$ and also the main cation present in the pickling liquor, which has been used to clean steel before any painting or electroplating operation. ${ }^{1}$

In fact, iron is ubiquitous in most solvent extraction circuits, because it is dissolved from the mineral feed during the leaching of desired metal by mineral acids $\left(\mathrm{HCl}, \mathrm{H}_{2} \mathrm{SO}_{4}, \mathrm{HNO}_{3}, \ldots\right)$ and some time was added to play the role of reductant, so, in all cases iron will affect the selectivity of extracted metal. $^{2}$
From health point of view, iron is an essential element in human nutrition. Estimates of minimum daily requirement for iron is in the range of 10-50 $\mathrm{mg} /$ day. But at high dose is fatal, the average lethal dose of iron is $200-250 \mathrm{~g} / \mathrm{kg}$ of body weight. ${ }^{3}$

So iron is not considered as dangerous as heavy metals $(\mathrm{Pb}, \mathrm{Cd}, \mathrm{Hg}, \ldots)$, but its concentration should not exceed $0.3 \mathrm{mg} / \mathrm{L}$ in drinking waters, because it contributes to bad taste, pipe clogging, and clothes, tube, sink, and teeth staining. ${ }^{4}$

Consequently, the recovery of iron(III) from aqueous wastewater is recommended. Since iron(III) is considered an annoying element if its concentration exceeds the permissible limits mentioned above.

A literature survey reveals that many of organophosphorous, amine, and amid extractants were

\footnotetext{
* Corresponding author: cscientific@aec.org.sy
} 
used to extract iron(III) from different aqueous (nitrate, chloride, sulphate, thiocyanate) media. ${ }^{5-18}$

M. T. Naik et al. ${ }^{11}$ reported that the extraction of $\mathrm{Fe}(\mathrm{III})$ from nitrate media using bis(2ethylhexyl) phosphinic acid, he mentioned that $\mathrm{Fe}$ (III) can be quantitatively extracted in the $\mathrm{pH}$ range 2-4.5 using $0.009 \mathrm{M}$ bis(2-ethylhexyl) phosphinic acid in hexane.

A. Sandhibigraha et al. ${ }^{12}$ found that $\mathrm{Fe}(\mathrm{III})$ extraction varies with $\mathrm{HCl}$ concentration, the loading capacity of $0.1 \mathrm{M}$ di-(2-ethyl hexyl) phosphoric acid (D2EHPA), 2-ethylhexyl phosphonic acid mono-2-ethyl hexyl ester (PC88A) and bis-(2,2,4 trimethylpentyl) phosphinic acid (Cyanex 272) was found to be 1.7, 1.3 and 1.8 $\mathrm{kg} / \mathrm{m}^{3}$ respectively. He mentioned that $\mathrm{Na}_{2} \mathrm{SO}_{4}$ and $\mathrm{NaCl}$ lowered the extraction efficiency while $\mathrm{NaNO}_{3}$ enhanced it.

X. H. Mao et al. ${ }^{13}$ investigated the extraction of $\mathrm{Ca}^{2+}, \mathrm{Mg}^{2+}, \mathrm{Al}^{3+}, \mathrm{Ti}^{4+}$ and $\mathrm{Fe}^{3+}$ from acidic chloride solutions by trioctylphosphine oxide (TOPO)/ kerosene, he showed that $\mathrm{Ti}(\mathrm{IV})$ and $\mathrm{Fe}(\mathrm{III})$ extractions increase with the increase of $\mathrm{HCl}$ concentration in the aqueous phase, leaving behind the other metal ions in the raffinate and that Ti(IV) and $\mathrm{Fe}(\mathrm{III})$ can be selectively recovered from the loaded organic phase by controlling the acidity of the stripping agent.

Bis-(2,2,4 trimethylpentyl) phosphinic acid in kerosene was tested to extract $\mathrm{Fe}(\mathrm{III})$ from aqueous sulphate media by I. M. Ahmad. ${ }^{14}$ and found that the stoichiometry of extracted metal species was in the form $\mathrm{Fe}\left(\mathrm{HSO}_{4}\right) \mathrm{A}_{2} \cdot 2\left(\mathrm{H}_{2} \mathrm{~A}_{2}\right)$ and the extraction equilibrium was calculated and found to be $(1.41 \pm 0.01) \times 10^{-2}$.

H. Watanabe et al. ${ }^{15}$ studied the extraction of $\mathrm{Fe}$ (III) from thiocyanate solutions using trioctylamine (TOA) dissolved in cyclohexane, xylene, toluene, carbon tetrachloride, benzene and chloroform. He found that the extractability of $\mathrm{Fe}(\mathrm{III})$ is roughly correlated with the dielectric constant of diluents; that is, the smaller the value of dielectric constant, the larger the extractability.

A solvent extraction experiment of $\mathrm{FeCl}_{3}$ in $\mathrm{HCl}$ solution with tri-octyl/decyl amine (Alamine 336) as extractant was conducted by Man-Seung Lee et al., ${ }^{16}$ he found that the equilibrium constant of solvent extraction reaction of $\mathrm{Fe}(\mathrm{III})$ by Alamine 336 were $\mathrm{L}_{\text {ex, }}=2.22 \times 10^{4}$ and $\mathrm{K}_{\mathrm{ex}, \mathrm{d}}=$ $6.41 \times 10^{5}$, and mechanism of extraction was presented as follows:

$$
\begin{aligned}
& \mathrm{Fe}^{3+}{ }_{(\mathrm{aq})}+4 \mathrm{Cl}^{-}{ }_{\text {(aq) }}+\mathrm{R}_{3} \mathrm{NHCl}_{\text {(org) }} \leftrightarrows \mathrm{FeCl}_{4} \mathrm{R}_{3} \mathrm{NH}_{\text {(org) }}+\mathrm{Cl}^{-}{ }_{\text {(aq) }} \\
& \mathrm{Fe}^{3+}{ }_{\text {(aq) }}+5 \mathrm{Cl}^{-}{ }_{\text {(aq) }}+2 \mathrm{R}_{3} \mathrm{NHCl}_{\text {(org) }} \leftrightarrows \mathrm{FeCl}_{5}\left(\mathrm{R}_{3} \mathrm{NH}\right)_{2 \text { (org) }}+2 \mathrm{Cl}^{-}{ }_{\text {(aq) }}
\end{aligned}
$$

A. V. L. N. S. H. Hariharan et al. ${ }^{17}$ reported that $\mathrm{Fe}(\mathrm{III})$ can be extracted quantitatively by tetrabutylammonium bromide from $\mathrm{HCl}, \mathrm{H}_{2} \mathrm{SO}_{4}$, $\mathrm{HNO}_{3}, \mathrm{HClO}_{4}$ media and $2 \mathrm{M} \mathrm{HCl}$ can strip completely iron (III) from the loaded organic phase.

M. C. Costa et al. ${ }^{18}$ studied the extraction of $\mathrm{Fe}$ (III) from acidic chloride solutions by N, N'dimethyl, N, N'-dibutylmalonamide (DMDBMA), $\mathrm{N}, \quad \mathrm{N}$-dimethyl-N,N'- diphenylmalonamide (DMDPHMA), N, N'-dimethyl-N,N'-diphenyl tetradecylmalonamide (DMDPHTDMA). $\mathrm{He}$ showed and clarified the important role played by the chemical structure on the metal ion transfer reactions to the organic phase and the selectivity towards $\mathrm{Fe}(\mathrm{III})$ and complete stripping of this metal by simple contact of the loaded organic phase (DMDBMA) with water.

This paper aims to investigate the recovery of $\mathrm{Fe}$ (III) from aquatic hydrochloric acid solutions by tri-n-dodecylamine/kerosene containing 2-octanol as modifier and using $2^{4}$ factorial design experiments to select and optimize the best operating conditions for $\mathrm{Fe}(\mathrm{III})$ recovery. As well as finding the best stripping conditions to strip $\mathrm{Fe}(\mathrm{III})$ from the loaded organic phase using $\mathrm{HCl}$ as stripping agent.

\section{EXPERIMENTAL}

\section{Reagents}

The reagents utilized in this work were: Ti-ndodecylamine used was obtained from Merck with more than 95\% purity. The kerosene used was from PEMCO SOLV 110 from PEMCO Chemicals Company and had as main properties: specific gravity 0.8 ; flash point $343.15{ }^{\circ} \mathrm{K}$; initial boiling point $473.15{ }^{\circ} \mathrm{K}$; final boiling point $523.15{ }^{\circ} \mathrm{K}$; aromatic content $<0.5 \%(\mathrm{v} / \mathrm{v})$. The hydrochloric acid $(37 \%)$ was obtained from Merck. The Iron nitrate nonahydrate $\mathrm{Fe}\left(\mathrm{NO}_{3}\right)_{3} \cdot 9 \mathrm{H}_{2} \mathrm{O}$ were from AppliChem company with $99 \%$ purity. 2- octanol was from BDH company with $97 \%$ purity.

\section{Aqueous phase preparation}

The aqueous phase of $\mathrm{Fe}^{3+}$ was prepared by dissolving the necessary amount of $\mathrm{Fe}\left(\mathrm{NO}_{3}\right)_{3} \cdot 9 \mathrm{H}_{2} \mathrm{O}$ and concentrated hydrochloric acid in double distilled water. 
Table 1

The aqueous and organic phase solutions used for $2^{4}$ factorial design extraction experiments

\begin{tabular}{|c|c|c|c|c|c|}
\hline & $\begin{array}{c}{[\mathrm{HCl}]_{\mathrm{i}}} \\
(\mathrm{M})\end{array}$ & $\begin{array}{l}\left(\mathrm{Fe}^{3+}\right)_{\mathrm{i}} \\
\left(\mathrm{g} / \mathbf{d m}^{3}\right)\end{array}$ & & $\begin{array}{c}{[\text { TDA }]_{i} / \text { kerosene }} \\
\text { (M) }\end{array}$ & $\begin{array}{c}\text { 2-Octanol } \\
(\%)\end{array}$ \\
\hline Aqueous Solution1 $\left(\Phi 1_{\mathrm{aq}}\right)$ & 0.5 & 1 & Organic phase 1 & 0.2 & 10 \\
\hline $\begin{array}{c}\text { Aqueous Solution2 } \\
\left(\Phi 2_{\mathrm{aq}}\right)\end{array}$ & 0.5 & 5 & $\left(\Phi 1_{\mathrm{org}}\right)$ & & \\
\hline $\begin{array}{l}\text { Aqueous Solution3 } \\
\left(\Phi 3_{\mathrm{aq}}\right)\end{array}$ & 2 & 1 & $\begin{array}{l}\text { Organic phase } 2 \\
\left(\Phi 2_{\text {org }}\right)\end{array}$ & 0.5 & 10 \\
\hline $\begin{array}{l}\text { Aqueous Solution4 } \\
\left(\Phi 4_{\mathrm{aq}}\right)\end{array}$ & 2 & 5 & & & \\
\hline
\end{tabular}

\section{Organic phase preparation}

The organic phases of tri-n-dodecylamine were prepared by dissolving the necessary amount of tri-n-dodecylamine in kerosene, 2- octanol was added as modifier to prevent third phase formation. Afterwards, each organic phase was preequilibrated with $\mathrm{HCl}$ solution which have the same concentration of $\mathrm{HCl}$ in the aqueous phase containing $\mathrm{Fe}^{3+}$.

\section{Necessary solutions for $2^{4}$ factorial design experiments}

Six solutions, 4 aqueous and 2 organic were prepared as shown in Table 1.

\section{Solvent extraction experiments and analysis}

The extraction experiments of $\mathrm{Fe}^{3+}$ were carried out at a constant temperature by shaking the aqueous phase and preequilibrated organic phases in a shaker bath thermostat (Grant OLS 200), after reaching the equilibrium, the phases were let to stand for $1 \mathrm{~h}$, then separated using separating funel. Iron in the aqueous phases before and after extraction was analyzed using Analytik Jena - Zeenit 700P atomic absorption spectrometer. And the concentration of iron in the organic phase was calculated by mass balance.

The distribution ratio $\left(\mathrm{K}_{\mathrm{d}}\right)$, the yield of iron(III) extraction $\left(\mathrm{Y}_{\mathrm{Fe}}{ }^{3+} \%\right)$ and the yield of iron(III) stripping ( $\mathrm{Y}^{\mathrm{Fe} 3+}{ }_{\text {strip } \%)}$ were respectively calculated as follows:

$$
\begin{gathered}
\mathrm{K}_{\mathrm{d}}=[\mathrm{Fe}]_{\text {org }} /[\mathrm{Fe}]_{\mathrm{aq}}, \\
\mathrm{Y}_{\mathrm{Fe}}{ }^{3+} \%=\left(\left([\mathrm{Fe}]_{\text {org. }} \cdot \mathrm{V}_{\text {org }}\right) /\left([\mathrm{Fe}]_{\mathrm{i}} \cdot \mathrm{V}_{\mathrm{aq}}\right)\right) \times 100, \\
\left.\mathrm{Y}^{\mathrm{Fe} 3+}{ }_{\text {strip }} \%=\left([\mathrm{Fe}]_{\mathrm{aq}} \cdot \mathrm{V}_{\mathrm{aq}}\right) /\left([\mathrm{Fe}]^{\text {org }}{ }_{\mathrm{i}} \cdot \mathrm{V}_{\text {org }}\right)\right) \times 100
\end{gathered}
$$

Where $[\mathrm{Fe}]_{\mathrm{i}},[\mathrm{Fe}]_{\mathrm{aq}},[\mathrm{Fe}]_{\text {org }}$ refers to concentration of iron in the aqueous phase before extraction, after extraction and organic phase respectively. $[\mathrm{Fe}]^{\text {org }}{ }_{\mathrm{i}}$ refers to initial concentration of iron in the organic phase before stripping.

\section{RESULTS AND DISCUSSION}

\section{Rate of $\mathrm{Fe}^{3+}$ extraction in the binary system $\left(\mathrm{Fe}^{3+}+\mathrm{HCl}\right) /(\mathrm{TDA} /$ kerosene $)$}

To determine the time necessary to reach the equilibrium of $\mathrm{Fe}^{3+}$ extraction by tri-ndodecylamine/kerosene, we studied the effect of time by shaking the organic phase of $0.5 \mathrm{M}$ TDA/kerosene containing 10\% 2-octanol with an aqueous phase of $2 \mathrm{M} \mathrm{HCl}$ containing $1 \mathrm{~g} / \mathrm{dm}^{3} \mathrm{Fe}^{3+}$ for different periods of time $(0-300 \mathrm{~min})$. The findings were shown in Fig. 1 displaying iron concentration in the aqueous and organic phase and distribution ratio $K_{d}$ as a function of time. From Fig. 1 we can clearly observe that the extraction of $\mathrm{Fe}^{3+}$ reaches the equilibrium at $1 \mathrm{~h}$ of shaking. Since $\mathrm{K}_{\mathrm{d}}, \mathrm{Fe}^{3+}{ }_{\text {org }}$ and $\mathrm{Fe}^{3+}{ }_{\text {aq }}$ are remaining constant after $1 \mathrm{~h}$ of shaking, all our experiments related to this study were carried out at $3 \mathrm{~h}$ of shaking to ensure the equilibration.

\section{Factorial design extraction experiments}

In order to study the effect of the four main factors $\left(\mathrm{Fe}^{3+}\right.$ concentration in the aqueous phase, $\mathrm{HCl}$ concentration, $\mathrm{O} / \mathrm{A}$ volume phase ratio and TDA content in the organic phase) on the yield of $\mathrm{Fe}^{3+}$ extraction by TDA/kerosene, a model of $2^{4}$ factorial design experiments was constructed as shown in Table 2 to optimize and understand the effect of each parameter on $\mathrm{Fe}^{3+}$ extraction and also the interaction between these parameters.

From Table 2 we can see that the best operating conditions $\left([\mathrm{HCl}]_{\mathrm{i}}=2 \mathrm{M}, \mathrm{O} / \mathrm{A}=3\right.$ and $[\mathrm{TDA}]_{\mathrm{i}}=$ $0.5 \mathrm{M}$ ) were observed in Test $\mathrm{N}^{\circ} 14$ and $\mathrm{N}^{\circ} 15$ for $\mathrm{Fe}=1 \mathrm{~g} / \mathrm{dm}^{3}$ and $\mathrm{Fe}=5 \mathrm{~g} / \mathrm{dm}^{3}$ respectively.

\section{Repeatability of $\mathrm{Fe}^{3+}$ extraction experiments}

To estimate the error on $\mathrm{Fe}^{3+}$ extraction yield by TDA/kerosene, four repeated experiments at the conditions presented in Table 3 were carried out. Taking into consideration the mean of the low and high values of the studied parameters $\left([\mathrm{HCl}]_{\mathrm{i}}=1.25 \mathrm{M},\left(\mathrm{Fe}^{3+}\right)_{\mathrm{i}}=3 \mathrm{~g} / \mathrm{dm}^{3}, \mathrm{O} / \mathrm{A}=2\right.$ and $\left.[\mathrm{TDA}]_{\mathrm{i}}=0.35 \mathrm{M}\right)$.

It can be clearly seen from Table 3 that the repeatability of $\mathrm{Fe}^{3+}$ extraction from $\mathrm{HCl}$ solution by TDA/kerosene is good. The average of $\mathrm{Y}_{\mathrm{Fe}}{ }^{3+} \%$ was found to be $94.87 \%$ with very small relative standard deviation $(\mathrm{RSD} \approx 0.11$ for $\mathrm{n}=4)$. 


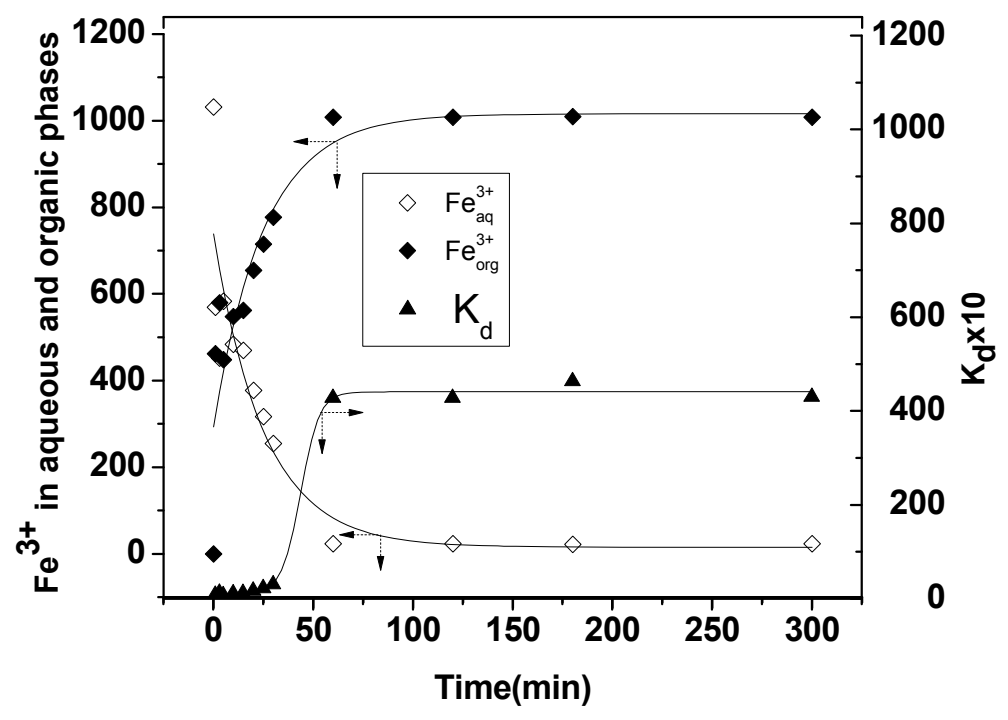

Fig. 1 - Extraction behavior of $\mathrm{Fe}^{3+}$ by TDA/kerosene as a function of time.

$[\mathrm{TDA}]_{\mathrm{i}}=0.5 \mathrm{M}+10 \% 2-\mathrm{octanol} /$ kerosene, $\left(\mathrm{Fe}^{3+}\right)_{\mathrm{aq}}=1 \mathrm{~g} / \mathrm{dm}^{3},[\mathrm{HCl}]_{\mathrm{i}}=2 \mathrm{M}, \mathrm{O} / \mathrm{A}=1, \mathrm{~T}=313.15^{\circ} \mathrm{K}$.

Table 2

$2^{4}$ factorial design matrix and the response and extraction conditions

\begin{tabular}{|c|c|c|c|c|c|c|c|c|c|}
\hline \multicolumn{10}{|c|}{ Extraction conditions: $\mathrm{T}=313.15^{\circ} \mathrm{K}$, shaking time $=3 \mathrm{~h}$} \\
\hline Tests & \multicolumn{4}{|c|}{ Reduced variables } & \multicolumn{4}{|c|}{ Real variables } & \multirow{2}{*}{$\frac{\text { Response function }}{\mathrm{Y}_{\mathrm{Fe}} \%}$} \\
\hline $\mathbf{N}^{\mathbf{0}}$ & $\mathbf{X}_{1}$ & $\mathbf{X}_{2}$ & $\mathbf{X}_{3}$ & $\mathbf{X}_{4}$ & $\begin{array}{r}{[\mathrm{HCl}]_{\mathrm{i}}} \\
(\mathrm{M})\end{array}$ & $\begin{array}{c}\left(\mathrm{Fe}^{3+}\right)_{\mathrm{i}} \\
\left(\mathrm{g} / \mathrm{dm}^{3}\right)\end{array}$ & $\mathbf{O} / \mathbf{A}$ & $\begin{array}{r}{\left[\mathbf{R}_{3} \mathbf{N}\right]_{i}} \\
(\mathbf{M})\end{array}$ & \\
\hline 1 & -1 & -1 & -1 & -1 & 0.5 & 1 & 1 & 0.2 & 43.160 \\
\hline 2 & +1 & -1 & -1 & -1 & 2 & 1 & 1 & 0.2 & 95.648 \\
\hline 3 & -1 & +1 & -1 & -1 & 0.5 & 5 & 1 & 0.2 & 15.300 \\
\hline 4 & +1 & +1 & -1 & -1 & 2 & 5 & 1 & 0.2 & 61.187 \\
\hline 5 & -1 & -1 & +1 & -1 & 0.5 & 1 & 3 & 0.2 & 68.053 \\
\hline 6 & +1 & -1 & +1 & -1 & 2 & 1 & 3 & 0.2 & 98.953 \\
\hline 7 & -1 & +1 & +1 & -1 & 0.5 & 5 & 3 & 0.2 & 42.167 \\
\hline 8 & +1 & +1 & +1 & -1 & 2 & 5 & 3 & 0.2 & 15.963 \\
\hline 9 & -1 & -1 & -1 & +1 & 0.5 & 1 & 1 & 0.5 & 89.597 \\
\hline 10 & +1 & -1 & -1 & +1 & 2 & 1 & 1 & 0.5 & 99.552 \\
\hline 11 & -1 & +1 & -1 & +1 & 0.5 & 5 & 1 & 0.5 & 59.487 \\
\hline 12 & +1 & +1 & -1 & +1 & 2 & 5 & 1 & 0.5 & 96.355 \\
\hline 13 & -1 & -1 & +1 & +1 & 0.5 & 1 & 3 & 0.5 & 95.980 \\
\hline 14 & +1 & -1 & +1 & +1 & 2 & 1 & 3 & 0.5 & 99.826 \\
\hline 15 & -1 & +1 & +1 & +1 & 0.5 & 5 & 3 & 0.5 & 90.539 \\
\hline 16 & +1 & +1 & +1 & +1 & 2 & 5 & 3 & 0.5 & 99.746 \\
\hline
\end{tabular}

Table 3

Repeatability of $\mathrm{Fe}^{3+}$ extraction experiments

\begin{tabular}{ccccccccc}
\hline $\begin{array}{c}\text { Experiment } \\
\text { number }\end{array}$ & $\begin{array}{c}{[\mathbf{H C l}]_{\mathbf{i}}} \\
(\mathbf{M})\end{array}$ & $\begin{array}{c}\left(\mathbf{F e}^{3+}\right)_{\mathbf{i}} \\
\left(\mathbf{g} / \mathbf{d m}^{3}\right)\end{array}$ & $\mathbf{O} / \mathbf{A}$ & $\begin{array}{c}{[\mathbf{T D A}]_{\mathbf{i}}} \\
(\mathbf{M})\end{array}$ & $\begin{array}{c}\mathbf{Y}_{\mathbf{F e}}{ }^{3+} \\
(\mathbf{\%})\end{array}$ & $\begin{array}{c}\overline{\mathbf{Y}}_{\mathbf{F e}}^{\mathbf{3}^{+}} \\
(\mathbf{\%})\end{array}$ & $\mathbf{S D}$ & $\mathbf{R S D}$ \\
\hline 1 & 1.25 & 3 & 2 & 0.35 & 94.91 & 94.87 & 0.103 & 0.109 \\
2 & 1.25 & 3 & 2 & 0.35 & 94.74 & & & \\
3 & 1.25 & 3 & 2 & 0.35 & 94.83 & & & \\
4 & 1.25 & 3 & 2 & 0.35 & 94.98 & & & \\
\hline
\end{tabular}

\section{Calculation of coefficients of $2^{4}$ factorial design experiments and their interactions}

The full general equation of $2^{4}$ factorial design experiments can be described as follows: ${ }^{19}$

$$
\begin{gathered}
Y=a_{0}+a_{1} X_{1}+a_{2} X_{2}+a_{3} X_{3}+a_{4} X_{4}+a_{12} X_{1} X_{2}+a_{13} X_{1} X_{3}+a_{23} X_{2} X_{3}+a_{14} X_{1} X_{4}+a_{24} X_{2} X_{4}+a_{34} X_{3} X_{4}+ \\
a_{123} X_{1} X_{2} X_{3}+a_{124} X_{1} X_{2} X_{4}+a_{134} X_{1} X_{3} X_{4}+a_{234} X_{2} X_{3} X_{4}+a_{1234} X_{1} X_{2} X_{3} X_{4}
\end{gathered}
$$


where each variable $X_{j}(j=1-4)$ takes two values -1 (low level) and +1 (high level).
From the results of $\mathrm{Fe}^{3+}$ extraction which was presented in Table 2, the following relationship was constructed:

$\mathrm{Y}_{\mathrm{Fe}}{ }^{3+} \%=73.221+10.184 \mathrm{X}_{1}-13.126 \mathrm{X}_{2}+3.183 \mathrm{X}_{3}+18.167 \mathrm{X}_{4}-1.964 \mathrm{X}_{1} \mathrm{X}_{2}-7.966 \mathrm{X}_{1} \mathrm{X}_{3}-1.173 \mathrm{X}_{2} \mathrm{X}_{3}-$ $2.699 X_{1} X_{4}+8.273 X_{2} X_{4}+1.954 X_{3} X_{4}-4.504 X_{1} X_{2} X_{3}+5.999 X_{1} X_{2} X_{4}+3.746 X_{1} X_{3} X_{4}+4.646 X_{2} X_{3} X_{4}+$ $1.809 \mathrm{X}_{1} \mathrm{X}_{2} \mathrm{X}_{3} \mathrm{X}_{4}$

Applying the same methodology of references 20 and 21, the equation (3) can be rewritten by replacing the reduced variables with the real variables $\left([\mathrm{HCl}],\left(\mathrm{Fe}^{3+}\right)_{\mathrm{aq}}, \mathrm{O} / \mathrm{A},[\mathrm{TDA}]\right)$ through the following relations:

$$
\mathrm{X}_{1}=\frac{\mathrm{B}-\mathrm{b}_{1}}{\mathrm{~b}_{2}}, \mathrm{X}_{2}=\frac{\mathrm{C}-\mathrm{c}_{1}}{\mathrm{c}_{2}}, \mathrm{X}_{3}=\frac{\mathrm{D}-\mathrm{d}_{1}}{\mathrm{~d}_{2}}, \mathrm{X}_{4}=\frac{\mathrm{E}-\mathrm{e}_{1}}{\mathrm{e}_{2}}
$$

$\mathrm{Y}_{\mathrm{Fe}}^{3+} \%=-33.241+63.549 \mathrm{~B}-5.443 \mathrm{C}+22.669 \mathrm{D}+258.142 \mathrm{E}+1.265 \mathrm{CD}+0.993 \mathrm{BC}-4.821 \mathrm{BD}$ $-122.325 \mathrm{BE}-16.619 \mathrm{CE}-44.889 \mathrm{DE}-5.818 \mathrm{BCD}+10.581 \mathrm{BCE}+5.433 \mathrm{CDE}+9.169 \mathrm{BDE}+8.042$ BCDE

where: B, C, D and E denotes [ $\mathrm{HCl}],\left(\mathrm{Fe}^{3+}\right)_{\mathrm{aq}}, \mathrm{O} / \mathrm{A}$ and [TDA] respectively.
And $\mathrm{b}_{1}, \mathrm{c}_{1}, \mathrm{~d}_{1}, \mathrm{e}_{1}, \mathrm{~b}_{2}, \mathrm{c}_{2}, \mathrm{~d}_{2}$ and $\mathrm{e}_{2}$ are calculated as follows:

$$
\begin{aligned}
& \mathrm{b}_{1}=\frac{\mathrm{B}_{\min }+\mathrm{B}_{\max }}{2}=1.25, \mathrm{c}_{1}=\frac{\mathrm{C}_{\min }+\mathrm{C}_{\max }}{2}=3, \mathrm{~d}_{1}=\frac{\mathrm{D}_{\text {min }}+\mathrm{D}_{\max }}{2}=2, \mathrm{e}_{1}=\frac{\mathrm{E}_{\min }+\mathrm{E}_{\max }}{2}=0.35 \\
& \mathrm{~b}_{2}=\frac{\mathrm{B}_{\text {max }}-\mathrm{B}_{\min }}{2}=0.75, \mathrm{c}_{2}=\frac{\mathrm{C}_{\text {max }}-\mathrm{C}_{\min }}{2}=2, \mathrm{~d}_{2}=\frac{\mathrm{D}_{\text {max }}-\mathrm{D}_{\min }}{2}=1, \mathrm{e}_{2}=\frac{\mathrm{E}_{\max }-\mathrm{E}_{\min }}{2}=0.15
\end{aligned}
$$

where: $\max$ and min refer to maximum and minimum value of studied variables.

All coefficients of equation (4) were calculated as described by Goupy and Creighton, ${ }^{19}$ and presented in Table 4 and also the importance of each coefficient on the general equation (Eq. 4) by using the term of $|\mathrm{a}| \mathrm{E}$, where $\mathrm{E}=\sigma / \sqrt{\mathrm{N}}=0.0258$. $\sigma$ is the standard deviation and $\mathrm{N}$ is the number of tests which have been carried out.

From Table 4 we can clearly see that the effect of individual parameter on the $\mathrm{Fe}^{3+}$ extraction yield follows the order:

$$
a_{4} / E>a_{2} / E>a_{1} / E>a_{3} / E
$$

Hence, $[\mathrm{TDA}]_{\mathrm{i}}>\left[\mathrm{Fe}^{3+}\right]_{\mathrm{i}}>[\mathrm{HCl}]_{\mathrm{i}}>\mathrm{O} / \mathrm{A}$ ratio. Consequently, the effect of amine concentration in the organic phase on $\mathrm{Fe}^{3+}$ extraction yield will be $5.7,1.78$ and 1.38 times bigger than $\mathrm{O} / \mathrm{A}$ volume phase ratio, $[\mathrm{HCl}]$ and $\mathrm{Fe}^{3+}$ concentration in the aqueous phase respectively. The most elevated binary and ternary interaction was observed for $\mathrm{X}_{2} \mathrm{X}_{4}=321.29$ and $\mathrm{X}_{1} \mathrm{X}_{2} \mathrm{X}_{4}=232.52$ respectively.

Deep observation of the calculated coefficients of equation 4 and their interactions will make us to conclude that all the sixteen coefficients are significant and none of them can be neglected and should be taken into consideration, since all $|a| / E$ values presented in Table 4 are bigger than t-test value $\left(\mathrm{t}_{0.95}=3.182\right.$ at $95 \%$ confidence level and degree of freedom $=3^{22}$ ).

By using equation 5, we studied graphically the effect of the four important variables [ $\mathrm{HCl}$, [TDA], $(\mathrm{Fe})_{\mathrm{aq}}$ and $\mathrm{O} / \mathrm{A}$ volume phase ratio on $\mathrm{Fe}(\mathrm{III})$ extraction yield as follows.

\section{Influence of $\mathrm{HCl}$ concentration in the aqueous phase on $\mathrm{Fe}^{3+}$ extraction}

Fig. 2 illustrates the effect of hydrochloric acid concentration on $\mathrm{Fe}^{3+}$ extraction by $0.5 \mathrm{M}$ $\mathrm{TDA} /$ kerosene containing 10\% 2-octanol at two different $\mathrm{O} / \mathrm{A}$ volume phase ratios 1 and 3 and two different $\mathrm{Fe}^{3+}$ concentrations $\left(1\right.$ and $\left.5 \mathrm{~g} / \mathrm{dm}^{3}\right)$ in the aqueous phase. It is seen from Fig. 2 that the yield of $\mathrm{Fe}^{3+}$ extraction increases with the rising of $\mathrm{HCl}$ concentration in the aqueous phase at constant $\mathrm{O} / \mathrm{A}$ volume phase ratio, $\mathrm{Fe}^{3+}$ concentration in the aqueous phase and TDA concentration in the organic phase. The highly positive effect of $\mathrm{HCl}$ concentration in the aqueous phase on $\mathrm{Y}_{\mathrm{Fe}}{ }^{3+} \%$ can be explained by the fact that the extractable species of $\mathrm{FeCl}_{4}^{-}$will be dominated at high $\mathrm{HCl}$ concentration, as described in equation 6 :

$$
\mathrm{Fe}^{3+}+4 \mathrm{Cl}^{-} \rightleftarrows \mathrm{FeCl}_{4}^{-}(\log \mathrm{K}=-1.31 \text { at } \mathrm{I}=0){ }^{16,23}
$$


Table 4

Calculated coefficients of $2^{4}$ factorial design experiments related to $\mathrm{Fe}^{3+}$ extraction yield and their effects on the general equation (Eq3)

\begin{tabular}{|c|c|c|c|c|c|c|c|c|}
\hline $\begin{array}{l}\text { Reduced } \\
\text { variables }\end{array}$ & Coefficient & Value & $\mathbf{E}=\boldsymbol{\sigma} / \sqrt{\mathbf{N}}$ & $|\mathbf{a}| / \mathbf{E}$ & Value & $\begin{array}{l}\text { Real } \\
\text { variables }\end{array}$ & Coefficient & Value \\
\hline Constant & $\mathrm{a}_{0}$ & 73.221 & & - & - & Constant & $\mathrm{k}_{0}$ & -33.241 \\
\hline $\mathrm{X}_{1}$ & $a_{1}$ & 10.184 & & $\left|\mathrm{a}_{1}\right| / \mathrm{E}$ & 395.51 & B & $\mathrm{k}_{1}$ & 63.549 \\
\hline $\mathrm{X}_{2}$ & $a_{2}$ & -13.126 & & $\left|\mathrm{a}_{2}\right| / \mathrm{E}$ & 509.73 & $\mathrm{C}$ & $\mathrm{k}_{2}$ & -5.443 \\
\hline $\mathrm{X}_{3}$ & $a_{3}$ & 3.183 & & $\left|\mathrm{a}_{3}\right| / \mathrm{E}$ & 123.62 & $\mathrm{D}$ & $\mathrm{k}_{3}$ & 22.669 \\
\hline $\mathrm{X}_{4}$ & $a_{4}$ & 18.167 & & $\left|\mathrm{a}_{4}\right| / \mathrm{E}$ & 705.51 & $\mathrm{E}$ & $\mathrm{k}_{4}$ & 258.142 \\
\hline $\mathrm{X}_{1} \mathrm{X}_{2}$ & $a_{12}$ & -1.964 & & $\left|\mathrm{a}_{12}\right| / \mathrm{E}$ & 76.29 & $\mathrm{BC}$ & $\mathrm{k}_{12}$ & 0.993 \\
\hline $\mathrm{X}_{1} \mathrm{X}_{3}$ & $a_{13}$ & -7.966 & 0.0258 & $\left|\mathrm{a}_{13}\right| / \mathrm{E}$ & 309.34 & $\mathrm{BD}$ & $\mathrm{k}_{13}$ & -4.821 \\
\hline $\mathrm{X}_{2} \mathrm{X}_{3}$ & $a_{23}$ & -1.173 & & $\left|\mathrm{a}_{23}\right| / \mathrm{E}$ & 45.56 & $\mathrm{CD}$ & $\mathrm{k}_{23}$ & 1.265 \\
\hline $\mathrm{X}_{1} \mathrm{X}_{4}$ & $a_{14}$ & -2.699 & & $\left|\mathrm{a}_{14}\right| / \mathrm{E}$ & 104.83 & $\mathrm{BE}$ & $\mathrm{k}_{14}$ & -122.325 \\
\hline $\mathrm{X}_{2} \mathrm{X}_{4}$ & $a_{24}$ & 8.273 & & $\left|\mathrm{a}_{24}\right| / \mathrm{E}$ & 321.29 & $\mathrm{CE}$ & $\mathrm{k}_{24}$ & -16.619 \\
\hline $\mathrm{X}_{3} \mathrm{X}_{4}$ & $a_{34}$ & 1.954 & & $\left|\mathrm{a}_{34}\right| / \mathrm{E}$ & 75.90 & $\mathrm{DE}$ & $\mathrm{k}_{34}$ & -44.889 \\
\hline $\mathrm{X}_{1} \mathrm{X}_{2} \mathrm{X}_{3}$ & $a_{123}$ & -4.504 & & $\left|\mathrm{a}_{123}\right| / \mathrm{E}$ & 174.93 & $\mathrm{BCD}$ & $\mathrm{k}_{123}$ & -5.818 \\
\hline $\mathrm{X}_{1} \mathrm{X}_{2} \mathrm{X}_{4}$ & $a_{124}$ & 5.999 & & $\left|\mathrm{a}_{124}\right| / \mathrm{E}$ & 232.99 & $\mathrm{BCE}$ & $\mathrm{k}_{124}$ & 10.581 \\
\hline $\mathrm{X}_{1} \mathrm{X}_{3} \mathrm{X}_{4}$ & $a_{134}$ & 3.746 & & $\left|\mathrm{a}_{134}\right| / \mathrm{E}$ & 145.46 & $\mathrm{BDE}$ & $\mathrm{k}_{134}$ & 9.169 \\
\hline $\mathrm{X}_{2} \mathrm{X}_{3} \mathrm{X}_{4}$ & $a_{234}$ & 4.646 & & $\left|\mathrm{a}_{234}\right| / \mathrm{E}$ & 180.41 & $\mathrm{CDE}$ & $\mathrm{k}_{234}$ & 5.433 \\
\hline $\mathrm{X}_{1} \mathrm{X}_{2} \mathrm{X}_{3} \mathrm{X}_{4}$ & $a_{1234}$ & 1.809 & & $\left|\mathrm{a}_{1234}\right| / \mathrm{E}$ & 70.27 & BCDE & $\mathrm{k}_{1234}$ & 8.042 \\
\hline
\end{tabular}

Moreover, maintaining constant the same experimental conditions with only changing $\mathrm{Fe}^{3+}$ concentration from 1 to $5 \mathrm{~g} / \mathrm{dm}^{3}$, the yield of $\mathrm{Fe}^{3+}$ extraction was decreased, but the quantity of $\mathrm{Fe}^{3+}$ extracted was increased which is in accordance with Le Chatelier's principle.

Meanwhile, at $\mathrm{O} / \mathrm{A}=3$, the yield of $\mathrm{Fe}^{3+}$ extraction is $>90 \%$ whatever $\mathrm{HCl}$ concentration in the aqueous phase, while at low $\mathrm{O} / \mathrm{A}$ volume phase ratio of 1 , the extraction behavior is generally similar to that obtained at $\mathrm{O} / \mathrm{A}=3$, but with lower $\mathrm{Y}_{\mathrm{Fe}} \%$. Since rising $\mathrm{O} / \mathrm{A}$ volume phase ratio will augment the number of moles of extractant in the organic phase which will consequently be in the favor of $\mathrm{Fe}^{3+}$ extraction.

\section{Influence of $\mathrm{Fe}^{3+}$ concentration in the aqueous phase on $\mathrm{Fe}^{3+}$ extraction}

It can be seen from Fig. 3, which represents the variation of $\mathrm{Y}_{\mathrm{Fe}}^{3+} \%$, as a function of $\mathrm{Fe}^{3+}$ concentration in the aqueous phase at $0.5 \mathrm{M}$ TDA/kerosene $+10 \%(\mathrm{v} / \mathrm{v})$ 2-octanol and at two different $\mathrm{HCl}$ concentrations 0.5 and $2 \mathrm{M}$ as well as two different volume phase ratios $\mathrm{O} / \mathrm{A}=1$ and 3 , that high acid concentration $2 \mathrm{M}$ will be in the favor of high $\mathrm{Fe}^{3+}$ extraction yield and lead to $\mathrm{Y}_{\mathrm{Fe}}{ }^{3+} \%$ is $>96 \%$ in the whole studied range of $\mathrm{Fe}^{3+}$ in the aqueous phase $\left(1-5 \mathrm{~g} / \mathrm{dm}^{3}\right)$. Increasing $\mathrm{O} / \mathrm{A}$ volume phase ratio from 1 to 3 improves $\mathrm{Y}_{\mathrm{Fe}}{ }^{3+} \%$. So, the concentration of $\mathrm{Fe}^{3+}$ have no big effect on the yield of $\mathrm{Fe}^{3+}$ extraction and the extraction is nearly complete when all studied parameters are in the high state level $\left(\mathrm{O} / \mathrm{A}=3, \quad[\mathrm{HCl}]_{\mathrm{i}}=2 \mathrm{M}\right.$, $\left.[\mathrm{TDA}]_{\mathrm{i}}=0.5 \mathrm{M}\right)$.
From Fig. 3 it is clear that $\mathrm{Y}_{\mathrm{Fe}}{ }^{3+} \%$ generally decreases with the increase of $\mathrm{Fe}^{3+}$ content in the aqueous phase at constant acidity and $\mathrm{O} / \mathrm{A}$ volume phase ratio, but the quantity of $\mathrm{Fe}^{3+}$ extracted will be higher. This can be attributed to the fact that the concentration of extractable species $\mathrm{FeCl}_{4}^{-}$will be higher at high initial $\mathrm{Fe}^{3+}$ concentration in the aqueous phase.

The most negative effect of $\mathrm{Fe}^{3+}$ concentration in the aqueous phase on the $\mathrm{Y}_{\mathrm{Fe}}{ }^{3+} \%$ was observed at $\left(\mathrm{O} / \mathrm{A}=1,[\mathrm{HCl}]_{\mathrm{i}}=0.5 \mathrm{M},[\mathrm{TDA}]_{\mathrm{i}}=0.5 \mathrm{M}\right)$ during the increase of $\mathrm{Fe}^{3+}$ concentration from 1 to $5 \mathrm{~g} / \mathrm{dm}^{3}$, since $\mathrm{Y}_{\mathrm{Fe}}{ }^{3+} \%$ was dropped from $89.6 \%$ to $59.5 \%$ but the quantity of $\mathrm{Fe}^{3+}$ extracted by TDA was increased from $0.896 \mathrm{~g}$ to $2.975 \mathrm{~g}$.

\section{Influence of TDA concentration in the organic phase on $\mathrm{Fe}^{3+}$ extraction}

Fig. 4 shows the effect of various concentration of TDA in kerosene $(0.2-0.5 \mathrm{M})$ containing $10 \%(\mathrm{v} / \mathrm{v})$ 2-octanol on $\mathrm{Fe}^{3+}$ extraction from hydrochloric acid solution of $2 \mathrm{M}$ at two different concentration of $\mathrm{Fe}^{3+}$ $\left(2\right.$ and $\left.5 \mathrm{~g} / \mathrm{dm}^{3}\right)$ in the aqueous phase and at organic to aqueous volume phase ratio $\mathrm{O} / \mathrm{A}=3$. As shown in Fig 4, the yield of $\mathrm{Fe}^{3+}$ extraction strongly increases with the increase of tri-n-dodecylamine concentration in the organic phase. Since the rise of TDA content in the organic phase will lead to high amine salt (TDA.HCl) concentration in the organic phase, then $\mathrm{Y}_{\mathrm{Fe}}{ }^{3+} \%$ will consequently increase, due to the availability of more free amine salt in the organic phase to react with $\mathrm{FeCl}_{4}^{-}$species present in the aqueous phase. 


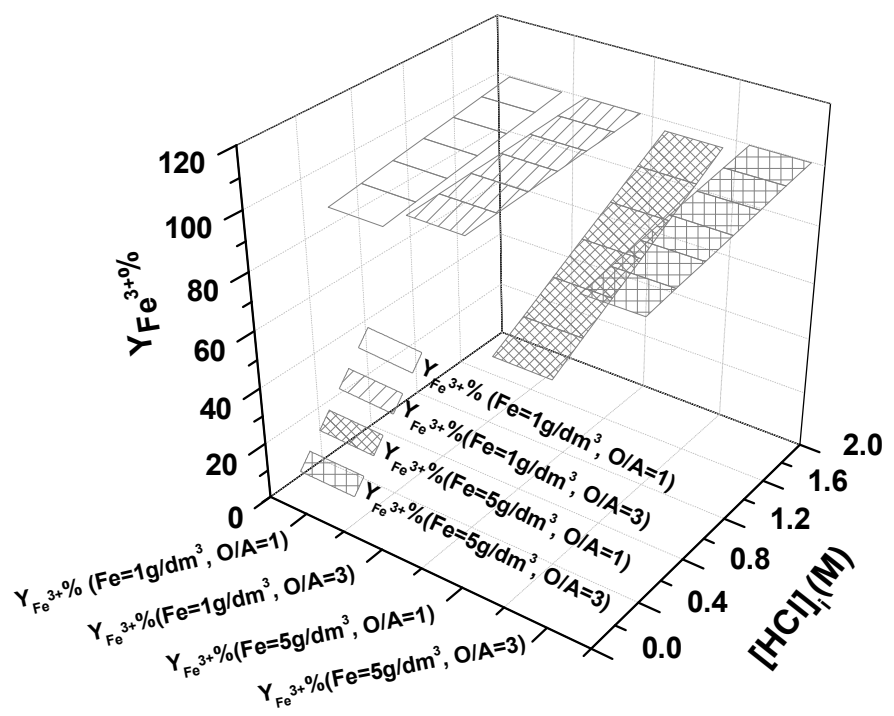

Fig. 2 - Relationship between initial $\mathrm{HCl}$ concentration and $\mathrm{Y}_{\mathrm{Fe}} 3+\%$.

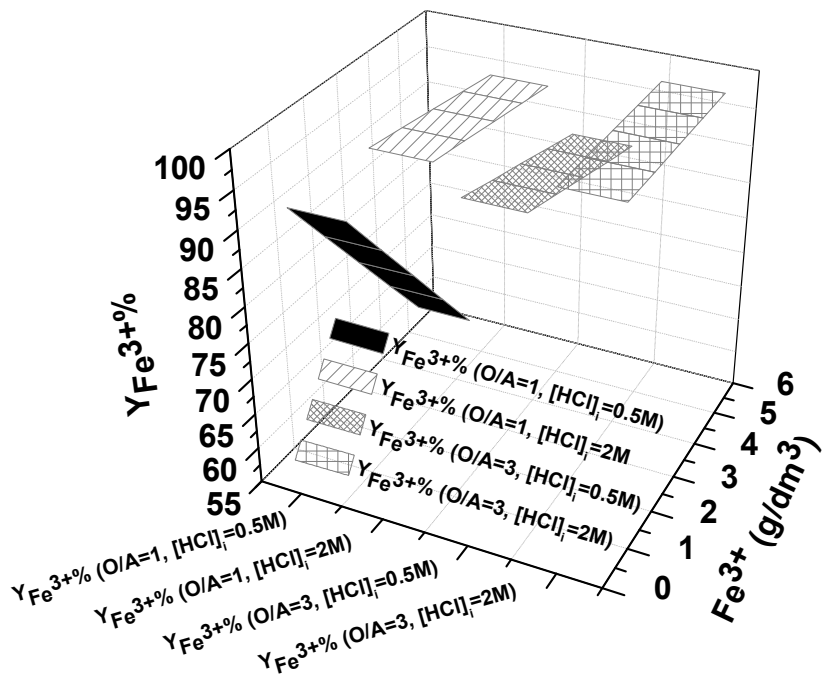

Fig. 3 - Relationship between $\mathrm{Fe}^{3+}$ concentration in the aqueous phase and $\mathrm{Y}_{\mathrm{Fe}}{ }^{3+} \%$.

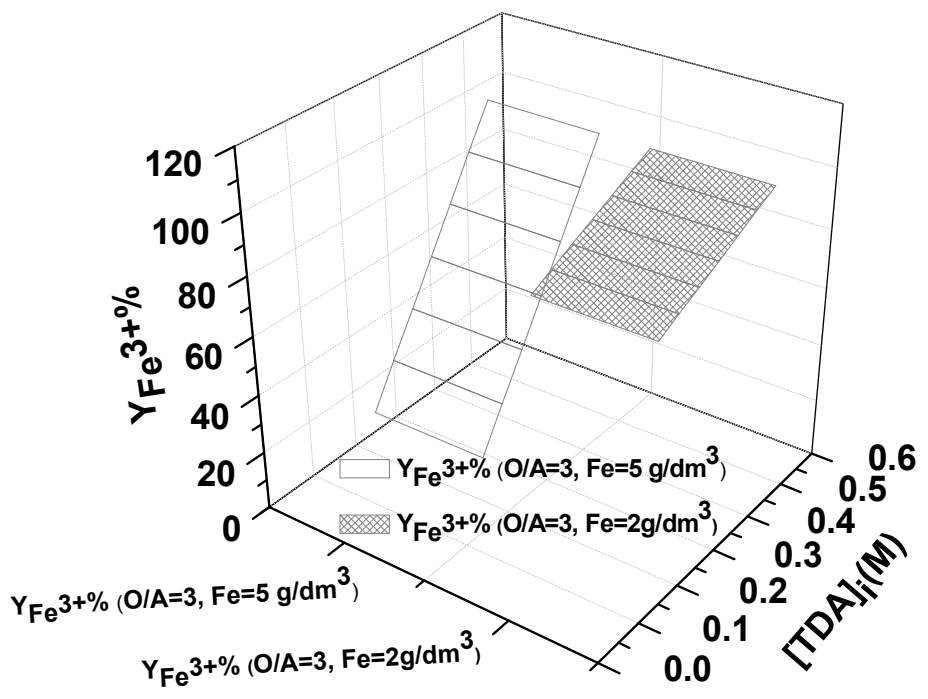

Fig. 4 - Relationship between TDA concentration and $\mathrm{Y}_{\mathrm{Fe}}{ }^{3+} \%$. 


\section{Influence of $\mathrm{O} / \mathrm{A}$ volume phase ratio on $\mathrm{Fe}^{3+}$ extraction}

It can be seen from Fig. 5 that the $\mathrm{Y}_{\mathrm{Fe}}{ }^{3+}$ increases with the increase of $\mathrm{O} / \mathrm{A}$ volume phase ratio at constant TDA concentration in the organic phase and iron concentration in the aqueous phase. The effect of $\mathrm{O} / \mathrm{A}$ volume phase ratio can clearly be observed at low acidity $0.5 \mathrm{M} \mathrm{HCl}$ than $2 \mathrm{M} \mathrm{HCl}$ and the $\mathrm{Y}_{\mathrm{Fe}}{ }^{3+} \%$ increases from $59 \%$ to $90.5 \%$ at $0.5 \mathrm{M} \mathrm{HCl}$ while at $2 \mathrm{M} \mathrm{HCl}$ the $\mathrm{Y}_{\mathrm{Fe}}{ }^{3+} \%$ increases from $96.4 \%$ to $99.8 \%$ with increasing $\mathrm{O} / \mathrm{A}$ volume phase ratio from 1 to 3 respectively.

Although, the $\mathrm{O} / \mathrm{A}$ volume phase ratio is the lower influencing parameter on $\mathrm{Fe}^{3+}$ extraction in comparison to TDA, $\mathrm{Fe}^{3+}$ concentration and $[\mathrm{HCl}]_{\mathrm{i}}$ parameters, but it should be taken in consideration especially when the extraction process is carried out at low acidity. To insure better transfer of $\mathrm{Fe}^{3+}$ from feed solution to the extractant.

\section{Influence of temperature on $\mathrm{Fe}^{3+}$ extraction}

To investigate the effect of temperature on $\mathrm{Fe}^{3+}$ extraction by TDA/kerosene, a $0.35 \mathrm{M}$ TDA/kerosene containing $10 \%$ 2-octanol solution was first pre-equilibrated with an aqueous acidic solution of $1.25 \mathrm{M}$ of $\mathrm{HCl}$ at $313.15{ }^{\circ} \mathrm{K}$ and $\mathrm{O} / \mathrm{A}=1$ volume phase ratio for $3 \mathrm{~h}$, then the amine salt obtained was put into contact with an aqueous solution of $1.25 \mathrm{M} \mathrm{HCl}$ containing $3 \mathrm{~g} / \mathrm{dm}^{3} \mathrm{Fe}^{3+}$, and shaked for $3 \mathrm{~h}$ at two organic to aqueous phase ratios $\mathrm{O} / \mathrm{A}=1$ and $\mathrm{O} / \mathrm{A}=2$ and at different temperatures (313.15,
$318.15, \quad 323.15, \quad 328.15$, and $333.15{ }^{\circ} \mathrm{K}$ ). The findings of $\mathrm{Fe}^{3+}$ extraction were demonstrated in Fig. 6 displaying $\log \mathrm{K}_{\mathrm{d}}$ and $\mathrm{Y}_{\mathrm{Fe}}{ }^{3+} \%$ as a function of absolute temperature $\mathrm{T}$ and $1 / \mathrm{T}$.

It can be seen from Fig. 6 that $\log \mathrm{K}_{\mathrm{d}}$ and $\mathrm{Y}_{\mathrm{Fe}}{ }^{3+} \%$ increase with increasing temperature, That's mean that the extraction reaction of $\mathrm{Fe}^{3+}$ by $\mathrm{TDA} /$ kerosene is endothermic, the enthalpy change $\Delta H^{\mathrm{O}}$ was calculated from Vantt Hoff equation and found to be $45.609 \mathrm{~kJ} / \mathrm{mol}$. The $\log \mathrm{K}_{\mathrm{d}}$ and $\mathrm{Y}_{\mathrm{Fe}}{ }^{3+} \%$ were also increased by increasing $\mathrm{O} / \mathrm{A}$ volume phase ratio from 1 to 2 .

\section{Loading capacity of tri-n-dodecylamine/kerosene}

An extractant solution of $0.35 \quad \mathrm{M}$ TDA $/$ kerosene $+10 \%$ 2-octanol was first of all pre-equilibrated by $2 \mathrm{M} \mathrm{HCl}$, then shaked with an aqueous phase of $2 \mathrm{M} \mathrm{HCl}$ containing $5 \mathrm{~g} / \mathrm{dm}^{3}$ $\mathrm{Fe}^{3+}$ for seven successive times. The results of $\mathrm{Fe}^{3+}$ extraction were presented in Fig. 7 in the form of $\mathrm{Fe}^{3+}{ }_{\text {org }}$ and $[\mathrm{TDA}]_{\mathrm{i}} /\left[\mathrm{Fe}^{3+}\right]_{\text {org }}$ against the number of contacts $\left(\mathrm{N}^{\prime}\right)$.

It is obvious from Fig. 7 that $\mathrm{Fe}^{3+}$ in the organic phase was increased and $[\mathrm{TDA}] /\left[\mathrm{Fe}^{3+}\right]_{\text {org }}$ was decreased with increasing $\mathrm{N}^{`}$. Then at $\mathrm{N}^{\prime} \geq 5$, the concentration of $\mathrm{Fe}^{3+}$ in the organic phase stayed constant and the saturation of the organic phase was attained at which the ratio $[\mathrm{TDA}] /\left[\mathrm{Fe}^{3+}\right]_{\text {org }}$ was found to be equal to 2.46 .

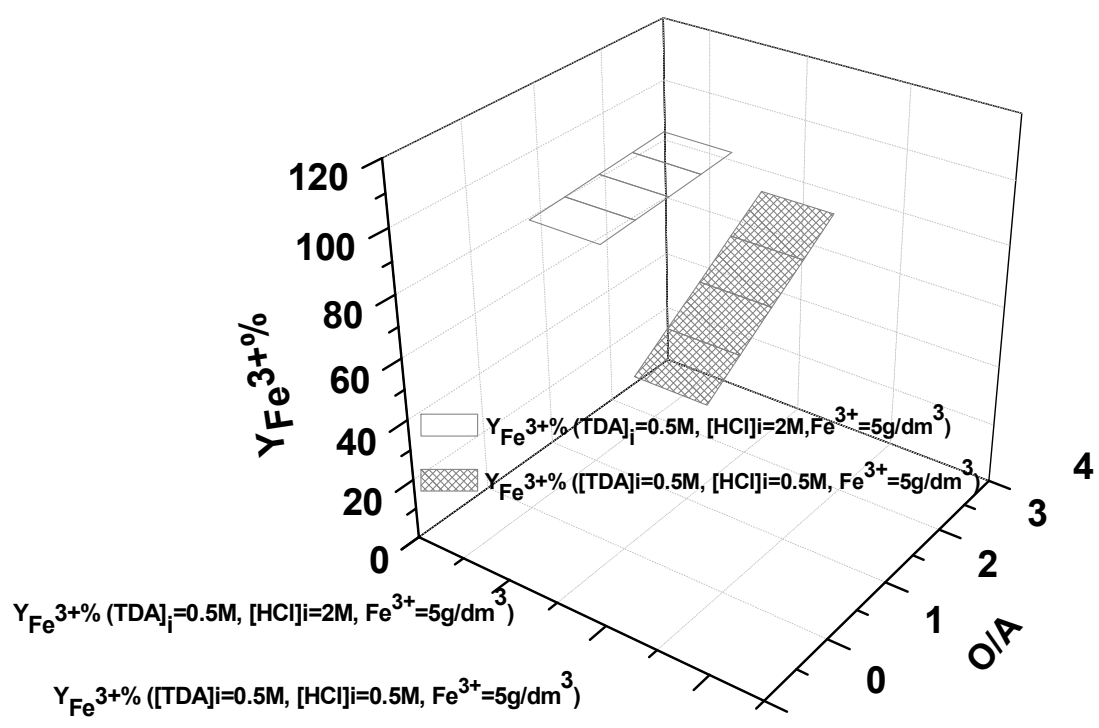

Fig. 5 - Relationship between $\mathrm{O} / \mathrm{A}$ volume phase ratio and $\mathrm{Y}_{\mathrm{Fe}}{ }^{3+} \%$. 


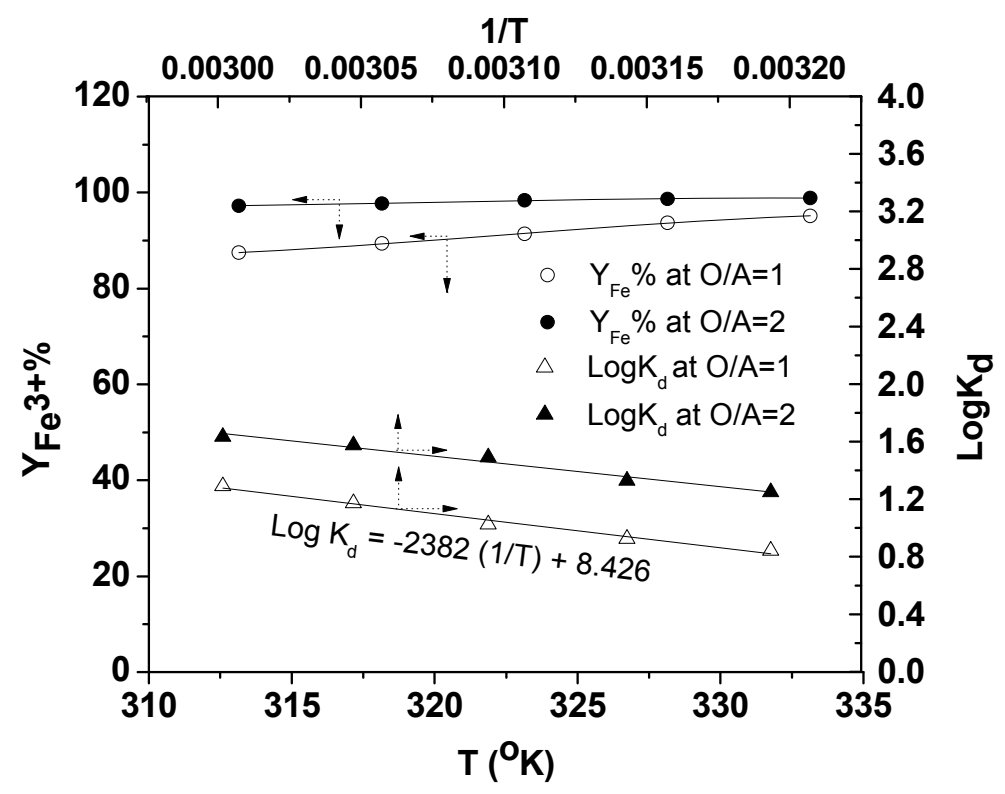

Fig. 6 - Relationship between temperature and $\mathrm{Y}_{\mathrm{Fe}}{ }^{3+} \%$ and $\log \mathrm{K}_{\mathrm{d}}$.

$[\mathrm{TDA}]_{\mathrm{i}}=0.35 \mathrm{M}+10 \% 2-$ octanol $/$ kerosene, $\left(\mathrm{Fe}^{3+}\right)_{\mathrm{aq}}=3 \mathrm{~g} / \mathrm{dm}^{3},[\mathrm{HCl}]_{\mathrm{i}}=1.25 \mathrm{M}$

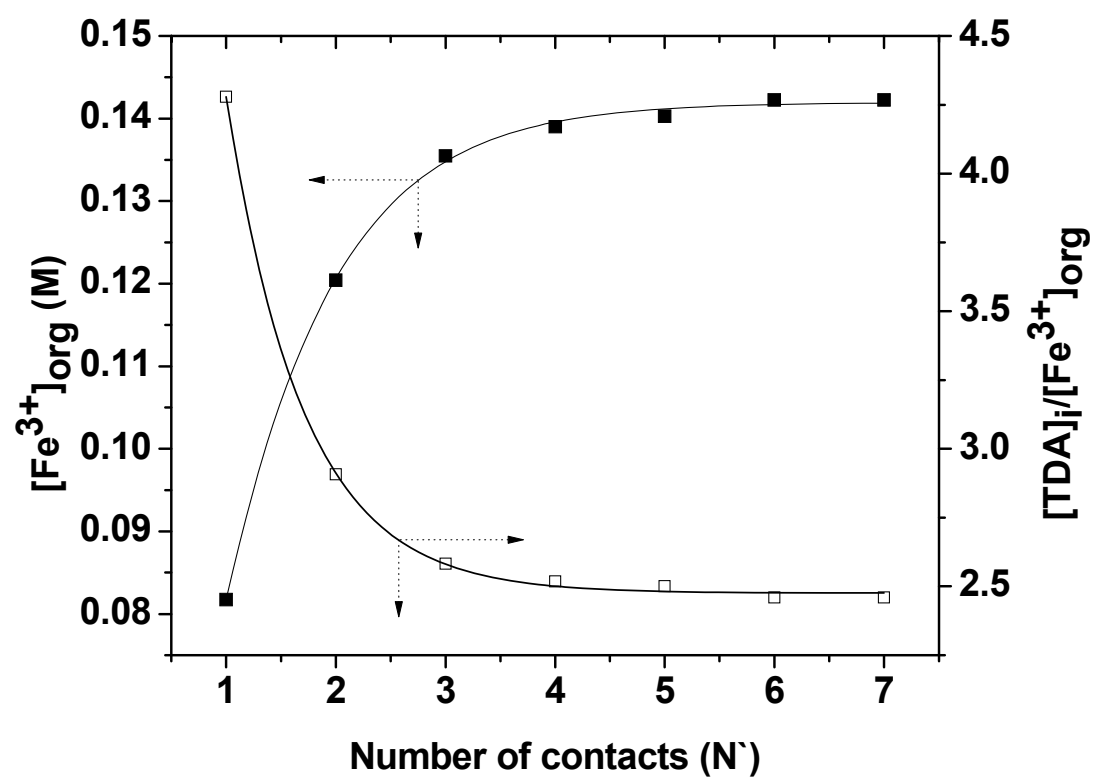

Fig. 7 - Relationship of $\left[\mathrm{Fe}^{3+}\right]_{\text {org }}$ and $[\mathrm{TDA}] /\left[\mathrm{Fe}^{3+}\right]_{\text {org }}$ against the number of contacts.

$[\text { TDA }]_{\mathrm{i}}=0.35 \mathrm{M} /$ kerosene $+10 \%$ 2-octanol, $\left(\mathrm{Fe}^{3+}\right)_{\mathrm{aq}}=5 \mathrm{~g} / \mathrm{dm}^{3}$

$\mathrm{O} / \mathrm{A}=1, \mathrm{~T}=313.15^{\circ} \mathrm{K}, \mathrm{N}^{`}=1,2,3,4,5,6,7$.

\section{Back extraction of $\mathrm{Fe}^{3+}$ from TDA/kerosene}

Stripping experiments were carried out by shaking the organic phase $0.35 \mathrm{M}$ TDA/ kerosene containing $10 \%$ 2-octanol as modifier and loaded with $4.509 \mathrm{~g} / \mathrm{dm}^{3}$ of $\mathrm{Fe}^{3+}$ with different concentration of $\mathrm{HCl}$ ranging from 0-5 $\mathrm{M}$, at two different temperatures 313.15 and $333.15^{\circ} \mathrm{K}$, and maintaining $\mathrm{O} / \mathrm{A}$ volume phase ratio constant and equal to 1 for $3 \mathrm{~h}$ of shaking. The results were presented in Fig. 8 in the form of $\mathrm{Y}_{\text {stripp }}^{\mathrm{Fe}} \%$ as a function of $\mathrm{HCl}$ concentration in the aqueous phase.

From Fig. 8 it can be clearly seen that the yield of $\mathrm{Fe}^{3+}$ stripping decreases with the increase of $\mathrm{HCl}$ concentration in the aqueous phase and also the temperature has a negative effect on $\mathrm{Y}^{\mathrm{Fe}}{ }_{\text {stripp }} \%$ from TDA/kerosene. The best $\mathrm{Y}_{\text {stripp }}^{\mathrm{Fe}} \% \approx 70 \%$ was observed at $[\mathrm{HCl}]=0.05 \mathrm{M}$, and Temp $=313.15^{\circ} \mathrm{K}$.

To optimize the stripping process and determine the best $\mathrm{A} / \mathrm{O}$ volume phase ratio to 
strip most of iron from the organic phase we studied the effect of $\mathrm{A} / \mathrm{O}$ volume phase ratio on $\mathrm{Fe}^{3+}$ stripping by conducting the stripping experiments at $[\mathrm{HCl}]=0.05 \mathrm{M}$ and $\mathrm{T}=313.15{ }^{\circ} \mathrm{K}$ and varying $\mathrm{A} / \mathrm{O}$ ratios from $1 / 16$ to $4 / 1$ the results were presented in Fig. 8 in the form of $\mathrm{Y}^{\mathrm{Fe}}{ }_{\text {stripp }} \%$ as a function of $\mathrm{A} / \mathrm{O}$ ratio. From Fig. 8 we can see that $\mathrm{A} / \mathrm{O}=4 / 1$ leads to a complete stripping of $\mathrm{Fe}^{3+}$ from TDA/kerosene. Consequently, the optimum conditions of iron stripping from $\mathrm{TDA} /$ kerosene are: $\left([\mathrm{HCl}]=0.05 \mathrm{M}, \mathrm{T}=313.15^{\circ} \mathrm{K}, \mathrm{A} / \mathrm{O}=4 / 1\right)$.

\section{Flowsheet for $\mathrm{Fe}^{3+}$ removal from aqueous $\mathrm{HCl}$ solutions}

Based on the data obtained from this study, we suggest the following flowsheet which is described in Fig. 9, to recover $\mathrm{Fe}^{3+}$ from aqueous $\mathrm{HCl}$ solutions by tri-ndodecylamine. The feed solution of $\mathrm{HCl}$ ( 2M) containing 1-5 g/ $\mathrm{dm}^{3} \quad \mathrm{Fe}^{3+}$ was put into contact with $0.5 \mathrm{M}$ TDA/kerosene $+10 \%$ 2-octanol in two extraction stages at $\mathrm{O} / \mathrm{A}=3$ and $313.15{ }^{\circ} \mathrm{K}$, then the loaded organic phase rich in $\mathrm{Fe}^{3+}$ was completely stripped in one cycle with diluted $\mathrm{HCl}$ solutions $(0.05 \mathrm{M})$ at $\mathrm{A} / \mathrm{O}=4$ ratio and $\mathrm{T}=313.15{ }^{\circ} \mathrm{K}$. The stripped organic phase is recycled, while the strip solution rich in iron(III) is subjected to evaporation process for $\mathrm{Fe}^{3+}$ concentration, after that the $\mathrm{Fe}^{3+}$ can be either precipitated with concentrated sodium hydroxide to obtain pure $\mathrm{Fe}(\mathrm{OH})_{3}$ after filtration, or crystallized to have pure $\mathrm{FeCl}_{3}$.

\section{CONCLUSION}

Factorial design experiments is a useful and effective method to optimize iron(III) extraction from $\mathrm{HCl}$ solutions, using limited number of experiments and reduce the quantity of chemicals used and cost.

The affinity between $\mathrm{Fe}^{3+}$ and TDA is clearly observed at high acid concentration where the extractable species of $\mathrm{FeCl}_{4}^{-}$is predominant.

Using high TDA concentration and $\mathrm{A} / \mathrm{O}$ volume phase ratio have positive effect on $\mathrm{Y}_{\mathrm{Fe}} \%$.

Temperature has positive effect on $\mathrm{Fe}^{3+}$ extraction which indicate that the extraction of iron(III) with TDA/kerosene is endothermic.

The saturation of TDA/kerosene is observed at number of contact $\left(\mathrm{N}^{\prime} \geq 5\right)$.

Stripping of iron from the loaded organic phase is simple and complete using either very diluted hydrochloric acid $(0.05 \mathrm{M})$ or water, and preferably diluted acid to accelerate phase separation during the settlement.

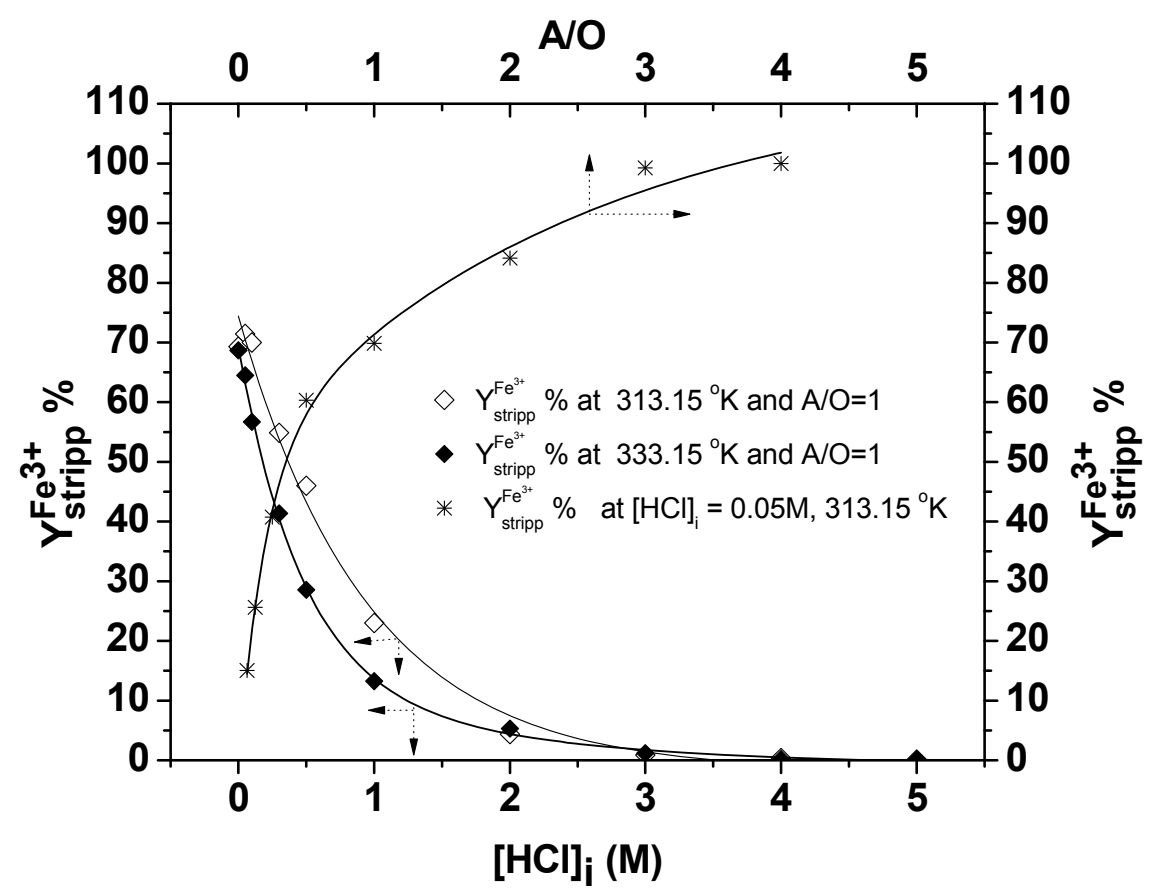

Fig. 8 - Back extraction of $\mathrm{Fe}^{3+}$ from the organic phase $0.35 \mathrm{M}$ TDA/kerosene. 


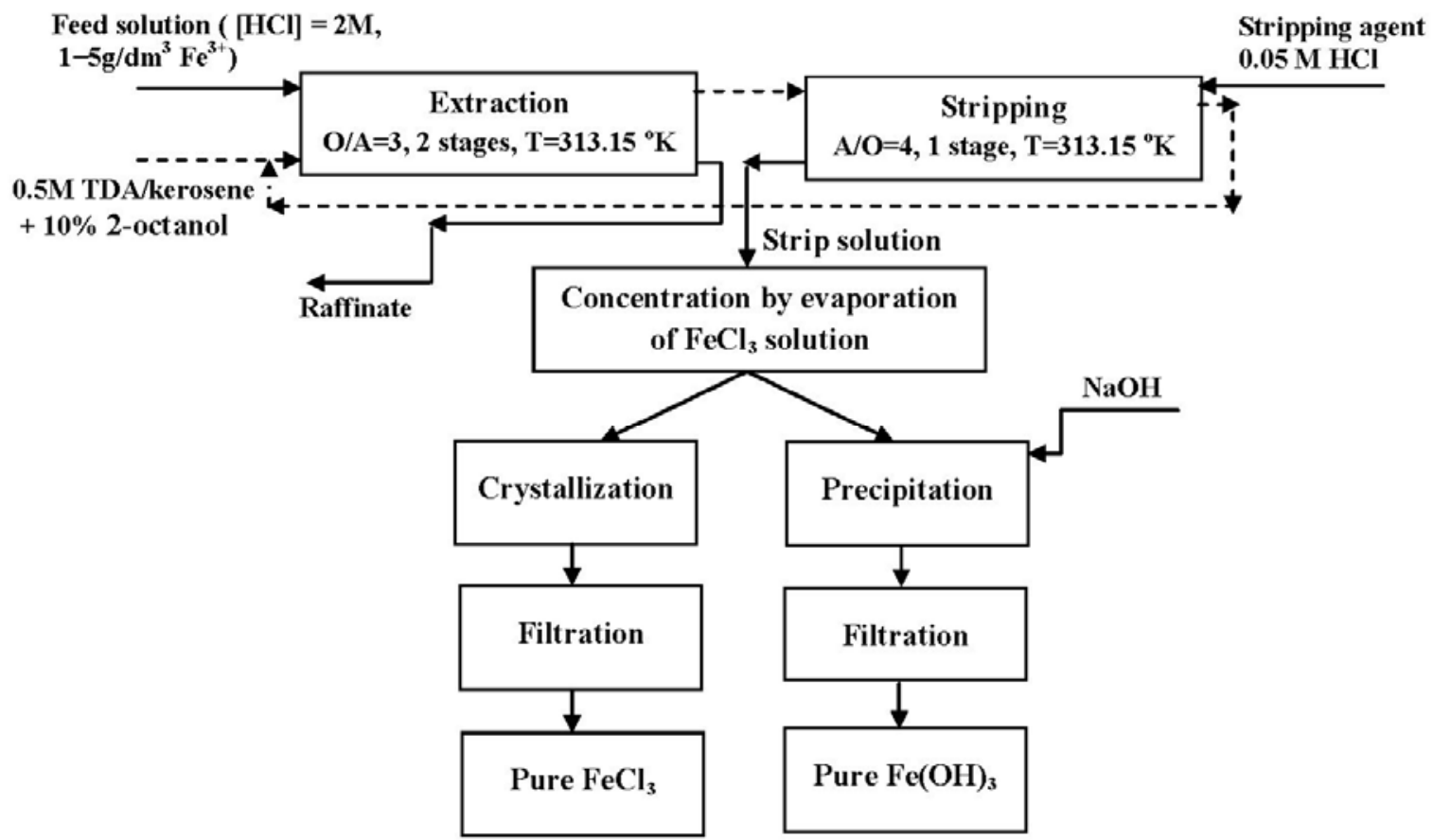

Fig. 9 - Suggested flow-sheet for iron(III) removal from aqueous hydrochloric acid solutions using tri-n-dodecylamine/kerosene +2 -octanol system.

Finally, we can say that the results obtained from this study could be very useful to: 1- recover iron from waste water, at first time by transforming all iron species to Fe(III) by simple oxidation step using hydrogen peroxide, then performing the extraction by TDA/kerosene $+10 \%$ 2- octanol. 2improve iron determination in very diluted aqueous solutions, by simple pre-concentration of iron using $\mathrm{TDA} /$ kerosene $+10 \%$ 2-octanol, then employing Atomic Absorption, Inductively coupled plasma techniques or UV-visible spectrophotometer for its determination 3- purification of iron(III) salts.

Acknowledgements. The authors are thankful to Prof. I. Othman (General Director of Atomic Energy Commission of Syria) for support and encouragement and financial support, thanks are also given to Prof Z. Ajji (Head of Chemistry Department) for providing valuable and enriching comments concerning the paper.

\section{REFERENCES}

1. X. Mao, $3^{\text {rd }}$ International Conference on Materials, Mechanical and Manufacturing Engineering (IC3ME2015), 27-28 June 2015, Guangzhou, China, p. 126-132.

2. D. Dreisingers, P. Littlejohn, Technical Review, "Copper Solvent Extraction in Hydrometallurgy", 2007. Available on line from http://www.scribd.com/document/323130668/ Littlejohn2007.pdf.
3. "Iron in Drinking-Water Background document for development of WHO Guidelines for Drinking-Water Quality", Vol 2, $2^{\text {nd }}$ edition, Geneva, 1996, World Health Organization.

4. "2018 Edition of the Drinking Water Standards and Health Advisories". U.S. Environmental Protection Agency, Washington, DC, 2018, pp 18. Available on-line from http://www.epa.gov/sites/production/files/201803/documents/dwtable2018.pdf

5. A.V.L.N.S.H. Hariharan, Ch. Sudhakar and B. Venkateswara Rao, Orient. J. Chem., 2012, 28, 17851790.

6. Li. Mingyu, He Zhimei, Zhou Li, Computer Distributed Control and Intelligent Environmental Monitoring, International Conference. 2011 (CDCIEM 2011), 19-20 February 2011, Changsha, Hunan, China, p 828-831.

7. M.Z. Ilic and R.W. Cattrall, Aust. J. Chem., 1984, 37, 489-495.

8. R.W. Cattrall, B.O. West, J. Inorg. Nucl. Chem., 1966, 28, 3035-3042.

9. D. Schrotterova and P. Nekovar, Chem. Papers., 1999, 53, 412-416.

10. X. H. Mao and D. J. Liu, Asian.J. Chem., 2013, 25, 4753-4756.

11. M. T. Naik and P. M. Dhadke, Indian J. Chem., 1999, 38A, 518-520.

12. A.Sandhibigraha, P.V.R. Bhaskara Sarmaand and V. Chakravortty. Scand J. Metall., 1996, 25, 135-140.

13. X. H. Mao, Proceedings of the $3^{\text {rd }}$ annual 2015 International Conference on Material Science and Environmental Engineering (ICMSEE2015), 5-6 June 2015, Wuhan, Huei, China, pp 145-150.

14. I.M. Ahmad, Arab J. Nucl- Sci, Appl., 2013, 46, 48-55.

15. H.Watanabe and M. Murozumi, Bull. Chem. Soc. Jpn., 1967, $40,1006-1007$. 
16. M.S. Lee, K. J. Lee and Y. J. Oh, Materials Transactions., 2004, 45, 2364-2368.

17. A. V. L. N. S. H. Hariharan, Ch. Sudhakar and B. Venkateswara Rao, Int. J. Anal. Biol. Chem., 2013, 3, 78-81.

18. M. C. Costa, M. Martins and A.P. Paiva, Separ. Sci. Technol., 2005, 39, 3573-3599.

19. J. Goupy and L. Creighton, "Introduction aux Plans d'Expériences", 3ed edition, Paris France, 2006, DUNOD.
20. C. K. Bayne, I. B. Rubin, "Practical Experimental Design and Optimization Methods for Chemists", Weinheim, W. Germany, 1986, VCH.

21. J. Stas, A. Dahdouh, H. Shlewit, S. Khorfan, Hydrometallurgy., 2002, 65, 23-30.

22. NIST/SEMATECH e-Handbook of Statistical Methods, http://www.itl.nist.gov/div 898/handbook/2013.

23. Y. Belaustegi, M. A. Olazabal and J. M. Madariaga, Fluid Phase Equilib., 1999, 155, 21-31. 